Отримано: 23 травня 2018 р.

Прорецензовано: 29 травня 2018 р.

Прийнято до друку: 01 червня 2018 р. e-mail: olha.demianchuk@oa.edu.ua
Дем'янчук О. I. Сутнісні характеристики та формування адміністративно-територіальних одиниць у контексті децентралізації регіонального розвитку. Наукові записки Національного університету «Острозька академія». Серія «Економіка» : науковий журнал. Острог : Вид-во НаУОА, червень 2018. № 9(37). С. 117-124.

Дем'янчук Ольга Іванівна,

\title{
СУТНІСНІ ХАРАКТЕРИСТИКИ ТА ФОРМУВАННЯ АДМІНІСТРАТИВНО-ТЕРИТОРІАЛЬНИХ ОДИНИЦЬ У КОНТЕКСТІ ДЕЦЕНТРАЛІЗАЦІЇ РЕГІОНАЛЬНОГО РОЗВИТКУ
}

У статті проведено методологічне дослідження сутнісних характеристик поняття «адміністративно-територіальні одиниці», на основі яких визначено, щчо цій категорії характерні такі ознаки: територіально-просторова, організаційна, правова, управлінська, системна, функціональна та ресурсна. Також автором проведено дослідження впливу прочесу децентралізаиї регіонального розвитку на формування нових адміністративно-територіальних одиниць. Охарактеризовано та визначено основні проблемні аспекти в законодавчому регулюванні цього прочесу. Результатом дослідження є виокремлення нових характерних ознак поняття «адміністративнотериторіальної одиниці» та ії форм у ході реалізачії реформи децентралізачії.

Ключові слова: адміністративно-територіальна одиниця, сутнісні ознаки адміністративно-територіальних одиниць, децентралізація регіонального розвитку, добровільно об'єднані територіальні громади.

Демьянчук Ольга Ивановна,

кандидат экономических наук, дочент кафедры финансов, учета и аудита, Национальный университет «Острожская академия»

\section{СУЩНОСТНЫЕ ХАРАКТЕРИСТИКИ И ФОРМИРОВАНИЯ АДМИНИСТРАТИВНО-ТЕРРИТОРИАЛЬНОЙ ЕДИНИЦЫ В КОНТЕКСТЕ ДЕЦЕНТРАЛИЗАЦИИ РЕГИОНАЛЬНОГО РАЗВИТИЯ}

В статье проведено методологическое исследование сущчностных характеристик понятия «административнотерриториальные единицы», на основе которых определено, что этой категории характерны следующие признаки: территориально-пространственная, организационная, правовая, управленческая, системная, функииональная и ресурсная. Также автором проведено исследование влияния прочесса децентрализаици регионального развития на формирование новых административно-территориальных единии. Охарактеризованы и определены основные проблемные аспекты в законодательном регулировании этого прочесса. Результатом исследования является выделение новых отличительных признаков понятия «административно-территориальной единиць» и ее форм в ходе реализации реформы децентрализации.

Ключевые слова: административно-территориальная единица, сущностные признаки административнотерриториальных единиц, деценттрализация регионального развития, добровольно объединены территориальные общиньл.

\section{Olha Demianchuk,}

PhD, associate professor of Finance, Accounting and Auditing Department,

The National University of Ostroh Academy

\section{ESSENTIAL CHARACTERISTICS AND FORMATION OF ADMINISTRATIVE-TERRITORIAL UNITS IN THE CONTEXT OF DECENTRALIZATION OF REGIONAL DEVELOPMENT}

In the article the methodological study of the essential characteristics of the notion of «administrative-territorial units» is conducted, based on which it is determined that this category is characterized by the following features: territorialspatial, organizational, legal, managerial, systemic, functional and resource-based. The author also carried out research on the impact of the process of the decentralization of regional development on the formation of new administrative-territorial units. In addition, the main problem aspects of legislative regulation of this process are characterized and identified in the research paper. The result of the study is the identification and highlight of new characteristic features of the concept of «administrative-territorial unit» and its forms during the implementation of the decentralization reform.

Key words: administrative-territorial unit, essential features of administrative-territorial units, decentralization of regional development, voluntarily united territorial communities. 
Постановка проблеми. Реформування територіальної організації влади й органів місцевого самоврядування в Україні стало об'єктивним наслідком економічної та політичної неефективності наявної вертикалі домінуючого централізованого державного управління. Зміни, які відбуваються у процесі децентралізації, створюють нову площину в системі державного управління в процесі іiі демократизації, забезпечують формування нової системи адміністративно-територіальних одиниць, які мали б бути спроможними надавати адміністративні, соціальні й інші послуги на рівні визначених державою стандартів, забезпечувати збалансований розвиток своїх територій. Проте брак чіткого законодавче закріпленого трактування сутнісної характеристики поняття «адміністративно-територіальної одиниці», а також наявність проблем, із якими стикаються новоутворенні територіальні одиниці та регіональні органи влади у процесі одержання нових повноважень, які не завжди $є$ фінансово забезпеченими для їх реалізації, створюють ризики для функціонування та соціально-економічного розвитку адміністративно-територіальних одиниць в Україні загалом.

Аналіз останніх досліджень і публікацій. На сьогодні значне коло науковців і практиків у свої фундаментальних наукових працях досліджують питання сутності поняття «адміністративно-територіальна одиниця» та її роль у формуванні органів місцевого самоврядування та забезпечення виконання ними владних функцій. Переважно зміст цього поняття розглядали більшість фахівці в галузі державного управління та місцевого самоврядування. Так, ряд науковців: О. Д. Лазор, В. Ф. Опришко, С. С. Саханенко, В. Г. Яцуба, досліджуючи сутність «адміністративно-територіальної одиниці», розуміють частину території держави, що $€$ просторовою основою для організації та діяльності місцевих органів державної влади й органів місцевого самоврядування $[9 ; 14$, с. 12; 22]. С. М. Серьогін, досліджуючи концептуальні засади децентралізації влади, стверджував, що «головне призначення місцевого самоврядування полягає у створенні та підтримці сприятливого життєвого середовища, необхідного для всебічного розвитку людини, надання мешканцям територіальних громад якісних і доступних адміністративних і соціальних послуг на основі сталого розвитку дієздатної громади [26]. Хоча не оминали цю проблематику 3 погляду соціально-економічної географії, зокрема фундаментальні праці Е. Б. Алаєва, Н. В. Багрова, В. А. Ржевського вказують на те, що адміністративно-територіальна одиниця як система $є$ віддзеркаленням територіальної структури держави як суперсистеми [4, с. 114], а конфігуратором системи управління є об'єктивні економіко-географічні зв'язки [3]. 3 погляду регіональної економіки, варто вказати на грунтовні дослідження М. І. Долішнього, Л. Т. Шевчук, М. О. Пухтинського, Ю. О. Чернецького, які стверджують, що територія конкретної територіальної суспільної системи не може бути довільною вона має межі, які зафіксовані в рамках системи адміністративно-територіального поділу держави [7, c. 8], а розуміння адміністративно-територіальної одиниці полягає в комплексі взаємозалежних інституцій та інших структурних елементів, кожний із яких робить внесок у загальну соціальну стабільність [27], саме побудова відповідних взаємин і системи органів публічної влади та певній адміністративній території, буде здатною надавати в межах соціальних стандартів повноцінні послуги населенню [19]. Більшість досліджень змісту поняття «адміністративно-територіальні одиниці» та реформування адміністративно-територіальної організації у процесі децентралізації грунтуються на прогресивних поглядах інституційно-правових, територіально-управлінських та регіональних аспектах. Поряд із цим питання глибокого сутнісного змісту категорії «адміністративно-територіальні одиниці» та формування нової системи адміністративно-територіальних одиниць у контексті децентралізації регіонального розвитку $\epsilon$ актуальним і потребує подальшого дослідження.

Мета дослідження полягає в методологічному визначенні сутнісної характеристики поняття «адміністративно-територіальні одиниці» та формуванні адміністративно-територіальних одиниць у контексті децентралізації регіонального розвитку. Для досягнення визначеної мети потрібно провести грунтовне дослідження змісту категорії «адміністративно-територіальні одиниці», визначити її сутнісні характеристики, а також дослідити особливості формування адміністративно-територіальних одиниць у процесі реалізації реформи децентралізації.

Виклад основного матеріалу. Кожна держава $є$ передусім політико-територіальною організацією публічної влади, тому територія держави - це невід'ємна ознака всякої державності і водночас просторова межа здійснення державної влади. Територіальна організація держави зводиться не лише до поділу іiі території на області, райони, населені пункти, тобто винятково лише до адміністративно-територіального устрою, зачіпає не лише сферу державно-правових відносин. Вона має набагато ширший характер, передбачає наявність територіальних одиниць, різних за своїм призначенням, між якими існують певні відносини. Саме в межах територіальної організації держави, яка базується на засадах адміністративного-територіального устрою відбувається формування їі елементів - адміністративно-територіальних одиниць.

У науковій літературі немає єдиного підходу до трактування поняття «адміністративно-територіальна одиниця». Здійснюючи методологічний аналіз, ми виокремимо сутнісні характеристики цієї категорії 3 різних поглядів. 
Згідно із законодавчо-правовою основою поняття «адміністративно-територіальної одиниці», на жаль, не має чіткого трактування. Так, Закон України «Про місцеве самоврядування в Україні» ст. 1 не дає визначення адміністративно-територіальної одиниці, а лише вказує на ії склад: область, район, місто, район у місті, селище, село [8]. Аналогічне трактування відбувається відповідно до Конституції України (ст. 133), адміністративно-територіальний поділ України становить цілісну систему адміністративно-територіальних одиниць, яка складається з Автономної Республіки Крим, областей, районів, міст, районів у містах, селищ і сіл [11]. Відповідно до рішення Конституційного Суду України адміністративно-територіальна одиниця - це компактна частина єдиної території України, що є просторовою основою для організації і діяльності органів державної влади й органів місцевого самоврядування [20].

Аналізуючи чинне законодавство на предмет правового закріплення змісту адміністративно-територіальної одиниці, приходимо до висновку, що в цих нормативних документах відображено перші дві сутнісні характеристики цього поняття - iї територіально-просторову ознаку й організаційну форму.

Так, у системі адміністративно-територіального устрою, згідно 3 досі чинним Законом про адміністративно-територіальний устрій, прийнятого ще 1981 року Указом Президії Верховної Ради Української УРСР, базовий рівень представлений міськими та сільськими населеними пунктами, тобто містами, селищами та селами [25]. До базового рівня інколи також відносять адміністративно-територіальні утворення, які склалися внаслідок добровільного об’єднання жителів кількох населених пунктів, на основі яких формуються органи місцевого самоврядування - сільські та селищні громади, місцеві ради. Присутність нечіткого законодавчого визначення адміністративно-територіальної одиниці первинного (або базового) рівня, постійне ототожнення ії з населеним пунктом зумовлюють існування таких територіальних утворень: селище міського типу, селище, район, район у місті та ін. Для прикладу, у частині першій статті 133, частинах четвертій, п'ятій статті 140 Конституції України і відповідно в абзаці третьому статті 1 Закону України «Про місцеві самоврядування в Україні», у частині першій статті 2 Закону України «Про столицю України - місто-герой Київ» район і район у місті визначають як окремі адміністративнотериторіальні одиниці, які мають різний правовий статус та інші відмінні ознаки.

Хоча адміністративно-територіальною одиницею $є$ не кожний населений пункт і не власне населений пункт, оскільки це поняття, скоріше, географічне, а один чи кілька населених пунктів із навколишніми землями, які перебувають під юрисдикцією єдиної для них територіальної громади та відповідних органів місцевого самоврядування.

Як указує у своєму монографічному дослідженні I. М. Скуратович, адміністративно-територіальна одиниця - це не лише населений пункт у межах забудови, а й частина території держави, на яку поширюється юрисдикція органу влади цієї території $[24$, с. 5].

Таким чином, наступною сутнісною характеристикою досліджуваного поняття є iї правова й управлінська ознаки, які мають забезпечувати чітке розмежування територій цих адміністративно-територіальних одиниць і визначати владні повноваження їх органів влади.

Тобто адміністративно-територіальну одиницю можна розглядати і як частину території держави, і як простір для організації та діяльності місцевих органів публічної влади. Водночас вона є об’єктом управління з боку цих органів.

Так, В. С.Кравців у своєму монографічному дослідженні, розглядаючи сутність адміністративно-територіального устрою країни, стверджує, що це поділ країни на адміністративно-територіальні одиниці певних рівнів, у яких формуються структура органів публічної влади, що забезпечують територіальне самоврядування й державне управління, та система адміністративно-управлінських, фінансово-економічних та інших взаємозв'язків між адміністративно-територіальними одиницями й центральними органами державної влади [1, с. 18].

3 погляду системного підходу адміністративно-територіальні одиниці постають у вигляді системи територіальної організації різних рівнів і сукупністю функціональних, фінансово-економічних, організаційних та адміністративно-управлінських взаємовідносин між її суб'єктами.

У науковій літературі з Конституційного права, В. В. Кравченко розрізняє адміністративно-територіальні одиниці за трьома ознаками:

- за місцем у системі адміністративно-територіального устрою України - на територіальні одиниці первинного рівня (міста без районного поділу, райони в містах, селища, села), середнього рівня (райони, міста з районним поділом) і вищого рівня (Автономна Республіка Крим, області, міста Київ і Севастополь);

- за своїм статусом - на: адміністративно-територіальні одиниці (області, райони), самоврядні територіальні одиниці (міста, селища, села). Крім того, як указує автор, АРК має особливий статус територіальної автономії, а райони в містах характеризуються ознаками як адміністративно-територіальних, так і самоврядних одиниць;

- за географічною ознакою вони поділяються на регіони (АР Крим, області, райони, міста-регіони Київ і Севастополь) та населені пункти (міста, селища, села). 
Також автор наголошує, що адміністративно-територіальна одиниця - це територіальна складова частина державної території, що не має будь-якої політичної самостійності і перебуває в підпорядкуванні центральних органів державної влади країни [13]. Підкреслюючи цим унітарний централізований механізм управління в системі адміністративно-територіального устрою України, а також наголошуючи на досить умовній самостійності органів місцевого самоврядування адміністративно-територіальних одиниць у прийнятті управлінський рішень.

Аналогічно стверджує професор В. Ф. Погорілко, що адміністративно-територіальні одиниці є штучно створеними формами територіальної організації центральною владою з метою визначення просторових меж для діяльності місцевих органів державної влади, а самоврядними $є$ такі територіальні одиниці, які слугують просторовою (територіальною) основою місцевого (регіонального) самоврядування [12].

Тому, які нові форми адміністративно-територіальних одиниць утворюються у процесі децентралізації регіонального розвитку і забезпечують функціонування самоврядних територіальних одиниць, ми розглянемо пізніше.

Повертаючись до сутнісної характеристики адміністративно-територіальної одиниці, наголошуємо на iii наступних двох ознаках - системний характер побудови та функціональні взаємовідносини.

Так С. С. Саханенко, обгрунтовуючи сутність адміністративно-територіальної одиниці, доповнює іiі такими системними атрибутами, як межі, назва, постійний центр, де здійснюються функції держави в особі як органів державної влади, так і органів місцевого самоврядування в частині делегованих державою повноважень [23, с. 47]. Аналогічно наголос на системності адміністративно-територіальної одиниці робить М. О. Пухтинський, стверджуючи, що вона відображає побудову відповідних взаємин і системи органів публічної влади на певній адміністративній території, яка б була здатна надавати в межах соціальних стандартів повноцінні послуги населенню [18, с. 35]. Як бачимо, для адміністративно-територіальної одиниці, характерний не лише системний принцип побудови, але і наявність функціональних взаємовідносин, які забезпечують реалізацію функцій і повноважень органів місцевого самоврядування.

Саме на цьому акцентує увагу А. Б. Гетьман, розкриваючи проблеми адміністративно-територіального реформування України, виділяє принцип системності, який відображає територіальну організацію держави з ііі внутрішнім поділом на складові частини - адміністративно-територіальні одиниці, які перебувають між собою в структурних і функціональних зв’язках. Хоча, автор також виділяє ще важливі два принципи характерні адміністративно-територіальному устрою країни та його складовим - це асиметричності розвитку його адміністративно-територіальних одиниць та стабільності адміністративнотериторіального устрою, який означає, що існуюча система адміністративно-територіальному устрою країни та ії складові повинні стабільно розвиватися, вдосконалюватися, пристосовуватись до існуючих суспільних трансформацій та змін [6, с. 35-36]. Забезпечення функціонування збалансованої системи адміністративно-територіальних одиниць в країні лише можливе за умови ефективного законодавства та сталого соціально-економічного розвитку економіки країни в цілому та ії окремих територіальних одиниць.

Погоджуючись із думкою С. І. Пирожкова й А. П. Павлюка, стверджуємо, що наступною сутнісною характеристикою поняття адміністративно-територіальної одиниці у процесі децентралізації регіонального розвитку є ефективність і раціональність використання всіх наявних і потенційних ресурсів, із метою створення самодостатніх адміністративно-територіальних одиниць. Зокрема, автори, досліджуючи принципи функціонування адміністративно-територіального устрою, наголошували на укрупненні масштабу адміністративно-територіальних одиниць із метою повного та раціонального використання ресурсів; зміцненні кадрового потенціалу місцевих органів влади; урахуванні особливостей регіональних систем розселення та прогнозів їхнього розвитку; науково-методичному опрацюванні всього комплексу питань адміністративно-територіальної реформи до початку іiі здійснення [15, с. 12]. Підтверджують цю сутнісну характеристику адміністративно-територіальної одиниці науковці Т. М. Безверхнюк, С. Є. Саханенко й Е. Х. Топалова, визначаючи регіональні принципи упорядкування адміністративно-територіального устрою, вказують на: самодостатність регіонів і територіальних громад; розв'язання проблем розвитку регіонів шляхом добровільного об'єднання зусиль органів місцевого самоврядування у сферах діяльності, що становлять спільний інтерес; однорідність території адміністративно-територіальних одиниць за певними ознаками чи їх поєднання; соціально-економічна цілісність і пов'язаність адміністративно-територіальних одиниць за критеріями (наявність адміністративного центру, спроможного обслуговувати територію, інфраструктурна транспортно-комунікаційна забезпеченість території, політико-адміністративний плюралізм) [5, с. 242-243].

Методологічний аналіз сутності поняття «адміністративно-територіальна одиниця» дає змогу зробити певні висновки. Адміністративно-територіальна одиниця за своєю природою $є$ територіальною та просторовою формою організації, яка створюється штучно для забезпечення ефективності територіального управління. Як система, адміністративно-територіальна одиниця є віддзеркаленням територіальної структури держави на основі їі адміністративно-територіального устрою, а їх взаємне узгодження та від- 
повідність є важливим ресурсом для підвищення управління територіальними утвореннями та виконання їх функцій. Ресурси всіх видів, якими володіє адміністративно-територіальна одиниця, забезпечують їі функціонування як соціально-економічної системи у складі держави, а також виконання органами місцевого самоврядування владних і делегованих повноважень. Основним суб'єктом адміністративно-територіальної одиниці, згідно з Конституцією України ст. 143, є територіальні громади села, селища, міста безпосередньо або через утворені ними органи місцевого самоврядування. Саме ці суб'єкти управляють майном, що є в комунальній власності цієї адміністративно-територіальної одиниці; затверджують програми соціально-економічного та культурного розвитку і контролюють їх виконання; затверджують бюджети відповідних адміністративно-територіальних одиниць і контролюють їх виконання [11]. Таким чином, адміністративно-територіальна одиниця, має ще одну сутнісну характерну ознаку - ресурсну, яка виражається через сукупність наявних і потенційних ресурсів усіх видів (природних, людських, фінансових та ін.), якими володіє ця територіальна одиниця.

Сутність адміністративно-територіальної одиниці не можливо розглядати без демократичних перетворень і сучасного процесу децентралізації регіонального розвитку.

Демократичні перетворення в Україні, які пройшли зі здобуттям незалежності, на жаль, не супроводжувалися відповідними змінами в системі адміністративно-територіального устрою, як наслідок, у формуванні адміністративно-територіальних одиниць існувало багато суперечностей. Також тривалий період в Україні зберігався адміністративно-територіальний устрій, який був сформований ще в часи СРСР. Цей устрій відповідав характеру тоталітарної політичної системи, яка панувала в часи Радянського Союзу. Він забезпечував повний контроль державної влади над громадянами, адміністративно-територіальними одиницями й місцевим самоврядуванням, які створювались штучно і носили формальний характер. Формування всіх владних інституцій здійснювалось бюрократичним шляхом, через закриті для суспільства канали. Хоча саме збереження елементів радянського типу адміністративно-територіального устрою в період незалежної України відіграло певну позитивну роль у забезпеченні та збереженні iii унітарності. Водночас ставало все очевиднішим невідповідність старої системи й принципів функціонування адміністративно-територіального устрою цілям демократичного розвитку країни, коли було прийнято в 1996 році Конституцію України, ст. 1 якої націлювала на побудову демократичної, соціальної та правової держави. Основні недоліки її проявлялися через домінування централізації, яка характеризувалась надто високою фінансовою, політичною та управлінською залежністю місцевого самоврядування від державної влади. Така система територіальної організації характеризувалась блокуванням потенціалу саморозвитку територіальних громад і регіонів, були низькі, а точніше сказати практично відсутні, можливості для реалізації ініціативності мешканців та органів управління адміністративно-територіальних одиниць базового рівня, насамперед сільських і селищних рад, у вирішенні питань місцевого значення й життєдіяльності громад. Наявні суперечності між новими суспільно-економічними відносинами та старою системою територіальної організації, яка характеризувалась часто створеними штучними формами адміністративно-територіальних одиниць і формальними органами самоврядування, значною мірою спричинила дисбаланси в розвитку територіальних утворень і неефективності використання їх наявних і потенційних ресурсів. Ратифікація Україною Свропейської хартії місцевого самоврядування та її євроінтеграційний вибір також поставили вимоги щодо внесення змін до системи адміністративно-територіального устрою держави, формування нових форм адміністративно-територіальних одиниць і їх органів місцевого самоврядування.

В основі цих змін став процес децентралізації регіонального розвитку, в основі якого відбувається децентралізація влади, територіальна децентралізація та розвиток місцевого самоврядування, при одночасній фінансовій і бюджетній децентралізації. 32015 року на основі схваленої Кабінетом Міністрів України Концепції реформування місцевого самоврядування та територіальної організації влади в Україні (розпорядження КМУ №333-р від 01.04.2014р.) розпочалося практичне втілення заходів, пов’язаних із завданням реформування адміністративно-територіального устрою у країні, зокрема, зі змінами в системі адміністративно-територіальних одиниць. Згідно з цим документом, в Україні закладено конституційні засади місцевого самоврядування, ратифіковано Свропейську хартію місцевого самоврядування, прийнято ряд базових нормативно-правових актів, які створили правові та фінансові основи для діяльності нових органів місцевого самоврядування [18].

Фактично відлік реформи децентралізації розпочався 5 лютого 2015 року, коли були прийняті два базових для цієї реформи закони, а саме Закон України «Про засади державної регіональної політики» та Закон України «Про добровільне об’єднання територіальних громад» [10]. Якщо перший закон мав значною мірою концептуальне значення, то другий створив реальний механізм об'єднання територіальних громад.

Згідно із Законом України № 157-УІІІ від 05.02.2015 р. «Про добровільне об’єднання територіальних громад» було утворено низку об'єднаних територіальних громад, як нових форм адміністративно-територіальних одиниць, які наділяються ширшими повноваженнями та дещо збільшеними ресурсними можливостями [10]. 
Таким чином, у процесі децентралізації регіонального розвитку, відбуваються такі зміни: створення нових базових форм адміністративно-територіальних одиниць, які наділені новими повноваженнями; в межах цих територіальних громад створено нові органи місцевого самоврядування, з метою підвищення якості надання ними послуг для населення цих територіальних утворень; цей процес супроводжується вищим рівнем децентралізації фінансових ресурсів і новими правилами міжбюджетних відносин. Кількарівневий принцип побудови нової системи адміністративно-територіальних одиниць покликаний забезпечити оптимальну керованість системи адміністративно-територіального устрою з поєднанням i задоволенням місцевих, а також регіональних інтересів із загальнодержавними. Водночас на кожному з рівнів адміністративно-територіальних одиниць забезпечується виконання певних владних повноважень із організації життєдіяльності відповідних спільнот мешканців і державного управління, а розподіл таких повноважень у сучасному баченні будується за принципом субсидіарності.

Проте внаслідок неузгодженості в законодавчому регулюванні створення та функціонування нових форм адміністративно-територіальних одиниць у вигляді добровільно об'єднаних територіальних громад (ОТГ), які утворюються зокрема в межах цілого району, як попередньо створеної та функціонуючої адміністративно-територіальної одиниці, виникає колізія щодо питання врегулювання функціонування подвійних органів місцевого самоврядування - виконавчі органи ОТГ, районної державної адміністрації (РДА) та районної ради. Тобто відбувається дублювання повноважень органів місцевого самоврядування ОТГ, районних рад і РДА. На сьогодні в межах таких адміністративно-територіальних одиниць одночасно функціонують райдержадміністрація та райрада із відповідними видатками на їх утримання, а також виконавчі органи ОТГ із визначеним законодавством повноваженнями та фінансуванням. Дуалізм влади на рівні місцевого самоврядування негативно впливає на процеси розподілу комунального майна між ОТГ і районом, ускладнює юрисдикцію органів виконавчої влади на території ОТГ, які утворенні в межах різних районів. Утворення, ліквідація, а також встановлення і зміна меж районів, відповідно до Конституції, є повноваженнями Верховної Ради України. Чотири варіанти подальших дій публічно озвучено було Мінрегіоном України [22]:

- змінити адміністративно-територіальний устрій районного рівня в межах усієї країни або території окремих областей;

- ліквідувати окремі райони, у яких усі територіальні громади об’єдналися;

- законодавчо врегулювати та достроково припинити повноваження райрад у районах, де всі громади об'єдналися в одну ОТГ; [16].

- утворити новий район шляхом об'єднання в один район територій двох і більше суміжних районів

Тому з метою вирішення всіх наявних колізій під час створення нових форм адміністративно-територіальних одиниць, у процесі реалізації реформи децентралізації в поточному році Кабінетом Міністрів України в лютому місяці подано законопроект «Про засади адміністративно-територіального устрою України» (від 22 лютого 2018 р.), з прийняттям якого та внесенням змін до Конституції України вирішаться всі спірні питання. Згідно зі ст. 4 вказаного законопроекту в системі адміністративно-територіального устрою України будуть формуватися адміністративно-територіальні одиниці регіонального, субрегіонального, базового та допоміжного рівнів. До адміністративно-територіальних одиниць регіонального рівня (регіонами) будуть входити Автономна Республіка Крим (АРК), області; до субрегіонального рівня - райони в АРК та в областях; адміністративно-територіальними одиницями базового рівня будуть громади, які утворюються на основі населених пунктів (сіл, селищ, міст); допоміжного рівня - райони в містах.

У законопроекті ст. 5 подано чітке визначення адміністративно-територіальної одиниці, як «частини території України в установлених відповідно до закону межах, що є територіальною основою для організації та діяльності державних органів та/або органів місцевого самоврядуванні» [17].

Посилаючись на ст. 2 законопроекту «Про засади адміністративно-територіального устрою України», поняття «адміністративно-територіальна одиниця» буде наділено такими характерними ознаками, сформованими у процесі децентралізації регіонального розвитку, а саме:

1) наявність адміністративного центру;

2) кадрова, інфраструктурна, фінансова спроможність органів місцевого самоврядування та місцевих органів виконавчої влади здійснювати визначені законом повноваження в повному обсязі;

3) відсутність у їі межах інших адміністративно-територіальних одиниць того ж рівня або адміністративно-територіальних одиниць нижчого рівня, що перебувають у юрисдикції інших адміністративно-територіальних одиниць того ж рівня;

4) нерозривність території адміністративно-територіальної одиниці;

5) наявність на території адміністративно-територіальної одиниці суб’єктів, спроможних надавати адміністративні, соціальні й інші послуги на рівні визначених державою стандартів; 
6) наявність на території адміністративно-територіальної одиниці соціально-культурної інфраструктури [17].

Проте на разі цей законопроект, пройшовши експертизу в першому читанні, отримав ряд слушних зауважень і повернуто суб'єкту права законодавчої ініціативи на доопрацювання. Хоча врегулювання законодавства в частині створення нової моделі адміністративно-територіального устрою $€$ найбільш необхідним та актуальним.

Неможливо оминути ще одні із проблем децентралізації регіонального розвитку щодо формування нових адміністративно-територіальних одиниць - це проблему законодавчого регулювання процесу об'єднання територіальних громад навколо міст обласного значення. Сутність цієї проблеми мала подвійну природу.

Створення нової територіальної громади з центром у місті обласного значення, з одного боку, вимагала проведення нових виборів міського голови та міської ради, що здебільшого суперечило інтересам депутатського корпусу та міських голів. Із другого боку, утворення об'єднаних територіальних громад шляхом приєднання до міської територіальної громади навколишніх сільських або селищних громад, також не співпадала з інтересами представників органів місцевого самоврядування, а також не завжди було чітке розуміння майбутніх голів ОТГ, які додаткові обов'язки потрібно буде забезпечувати щодо розвитку інфраструктури цих населених пунктів, надання відповідних суспільних послуг.

У ході реформи децентралізації 3 квітня 2018 року Верховна Рада України прийняла у другому читанні законопроект № 6466 щодо добровільного приєднання територіальних громад до міст обласного значення. Відтепер громади можуть за спрощеною процедурою приєднуватися до міст обласного значення і створювати нові форми адміністративно-територіальних одиниць.

Висновки. Узагальнюючи методологічні дослідження сутності поняття «адміністративно-територіальна одиниця», подаємо авторське трактування. Адміністративно-територіальна одиниия - це цілісна частина території України з законодавчо встановленими межами, як система має відповідну ресурсну базу, сукупність організаційних, адміністративно-управлінських і фінансово-економічних взаємовідносин, а також $є$ базовою територіальною основою (з адміністративним центром) для організації та діяльності органів місцевого самоврядування та їх взаємодії з центральними органами влади.

Проведений аналіз особливостей формування адміністративно-територіальних одиниць у ході реалізації процесу децентралізації, дав змогу виокремити основні проблемні аспекти законодавчого регулювання створення нових територіальних утворень у вигляді об'єднаних територіальних громад. Для вирішення яких, насамперед, повинно бути врегульовано конституційне забезпечення адміністративнотериторіальної реформи, оскільки окремі важливі елементи ії проведення входять у суперечність із положеннями чинної Конституції України. Тому виникає колізія двовладдя в ОТГ, які формуються в межах попередньо діючих адміністративно-територіальних одиниць - районів. Також суперечливим $\epsilon$ намагання децентралізувати владні повноваження, перекласти низку важливих соціальних функцій, зокрема у сфері освіти, охорони здоров'я, на територіальні громади, як нові базові форми адміністративно-територіальних одиниць, без відповідної децентралізації в бюджетно-фінансовій сфері.

Саме прийняття законопроекту «Про засади адміністративно-територіального устрою України» може забезпечити вирішення ряд проблем у формуванні нової системи адміністративно-територіальних одиниць. У законопроекті зазначено, що ця система має залишитися трирівневою. Водночас передбачено, що районний рівень має бути більш упорядкований і відповідати європейським стандартам. Крім того, у законопроекті більш чітко визначено поняття «громада», як адміністративно-територіальна одиниця базового рівня, яка складається з одного або декількох населених пунктів і земель за їх межами. Громада «€ територіальною основою для здійснення місцевого самоврядування жителями населених пунктів, що розташовані на території громади, формування і діяльності органів місцевого самоврядування» [17].

На основі методологічного дослідження й аналізу особливостей впливу процесу децентралізації на формування системи адміністративно-територіальних одиниць, ми можемо виокремити сутнісні характеристики, які були характерні адміністративно-територіальній одиниці та сформовані у процесі утворення iï нових форм. Отже, для адміністративно-територіальних одиниць характерні такі ознаки: територіально-просторова, цілісна й організаційна форма утворення; законодавчо-правова й адміністративно-управлінська сфера діяльності; система функціональних, фінансово-економічних і соціальних взаємовідносин у межах територіального утворення та з органами центрального управління.

Головні напрями подальших наукових досліджень мають бути спрямовані на визначення особливостей створення та функціонування територіальних громад, як базових адміністративно-територіальних одиниць у процесі реалізації наступних етапів децентралізації в Україні. 


\section{Література:}

1. Адміністративно-територіальний устрій України: методологічні основи та практика реформування: монографія / ДУ «Інститут регіональних досліджень імені М.I. Долішнього НАН України»; наук. ред. В.С. Кравців. Львів, 2016. 264 с.

2. Адміністративно-територіальний устрій України. Шляхи реформування: монографія / В.Г. Яцуба, В.А. Яцюк, О.Я. Матвї̈шин та ін. Київ, 2007. 366 с.

3. Алаев Э.Б. Экономико-географическая терминология. - М., 1977. - 199 с.

4. Багров Н.В. Региональная геополитика устойчивого развития. К.: Лыбидь, 2002. 256 с.

5. Безверхнюк Т.М. Свропейські стандарти врядування на регіональному рівні: монографія / Т.М. Безверхнюк, С.С. Саханенко, Е.Х. Топалова / [за заг. ред. Т.М. Безверхнюк]. - Одеса: ОРІДУ АДУ, 2008. 328 с.

6. Гетьман А.Б. Конституційно-правові засади адміністративно-територіального устрою України [Текст]: дис. ... канд. юрид. наук: 12.00.02 / Гетьман Андрій Борисович; Інститут держави і права ім. В. М. Корецького НАН України. Київ, 2013. 190 с.

7. Долішній М.І., Шевчук Л.Т., Шевчук Я.В. Територіальна суспільна система як об'єкт дослідження регіональної економіки України. Соціально-економічні дослідження в перехідний період. Регіональні суспільні системи: 3б. наук. пр. / НАН України; Ін-т регіон. дослідж.; Відп. ред. М.І.Долішній. - Л., 2004. - Вип. 3 (XLVII). - Ч. 1. - C. 3-12.

8. Закон України «Про місцеве самоврядування в Україні». Верховна Рада України, № 280/97-ВР від 21.05.1997. URL: http://zakon5.rada.gov.ua/laws/show/280/97-\%D0\%B2\%D1\%80 (дата звернення: 24.05.2018).

9. Закон «Про місцеве самоврядування в Україні»: Наук.-практ. комент. / Голов. ред. В.Ф.Опришко. - К., 1999. - $397 \mathrm{c}$

10. Закон України «Про добровільне об’єднання територіальних громад» Верховна Рада України; № 157 VIII від 05.02.2015. URL: http://zakon2.rada.gov.ua/laws/show/157-19 (дата звернення: 22.05.2018).

11. Конституція України від 28 червня 1996 року//Відомості Верховної Ради України. - 1996. - № 30 (23.07. 1996). - Ст. 141

12. Конституційне право України / За ред. професора В. Ф. Погорілка. - Київ: Наукова думка, 1999. 610 с.

13. Кравченко В. В. Конституційне право України: Навчальний посібник. Вид. 3-тє, виправл. та доповн. - К.: Атіка, 2004, 512 с.

14. Лазор О. Д., Лазор О. Я., Чемерис А. О. Територіальна організація влади в Україні. - К.: Дакор, 2007. - 576 с.

15. Пирожков С. І., Павлюк А. П. Адміністративно-територіальна реформа в Україні: актуальні питання методології та практики. Економіка Украӥни. 2005. № 6. С. 5-16.

16. Проект Закону «Про порядок утворення, ліквідації районів, встановлення і зміни їх меж» Верховна Рада України; № 6636 від 22.06.2017. URL: http://w1.c1.rada.gov.ua/pls/zweb2/webproc4_1?pf3511=62118 (дата звернення: 24.05.2018).

17. Проект Закону «Про засади адміністративно-територіального устрою України», Верховна Рада України; № 8051 від 22.02.2018. URL: http://w1.c1.rada.gov.ua/pls/zweb2/webproc4_1?pf3511=63508 (дата звернення: 22.05.2018).

18. Про схвалення Концепції реформування місцевого самоврядування та територіальної організації влади в Україні Кабінет Міністрів України; Розпорядження, Концепція від 01.04.2014 № 333-p URL: http://zakon5. rada.gov.ua/laws/show/333-2014-\%D1\%80 (дата звернення: 22.05.2018).

19. Пухтинський М. Концептуальні та прикладні аспекти здійснення адміністративної реформи в Україні. Адміністративна реформа в Украӥні: илях до Європейської інтеграції: 3б. наук. пр. К., 2003. С. 33-35.

20. Рішення Конституційного Суду України у справі за конституційним поданням народних депутатів України щодо [...] Конституційний Суд; Рішення від 13.07.2001 № 11-рп/2001 URL: http://zakon5.rada.gov.ua/ laws/show/v011p710-01 (дата звернення: 21.05.2018).

21. Ржевский В. А. Территориальная организация Советского государства. - Саратов, 1966. - 153 с.

22. Сайт «Децентралізація влади»: «Геннадій Зубко запропонував чотири варіанти зміни адміністративно -територіального устрою» URL: http://decentralization.gov.ua/news/7057 (дата звернення: 19.05.2018).

23. Саханенко С. Адміністративно-територіальний та муніципально-територіальний устрій: проблеми співвідношення та реформування. Управління сучасним містом. 2001. № 4-6. С. 45-53.

24. Скуратович I. М. Адміністративно-територіальний устрій України в 1920-1930-х рр. і його вплив на організацію державного управління: історико-правове дослідження: монографія. Х.:Видавець СПДФО Вапнярчук Н.M., 2004. - 192 с.

25. Указ Президії Верховної Ради УРСР від 12 березня 1981 року «Про затвердження Положення про порядок вирішення питань адміністративно-територіального устрою Української РСР»//Відомості Верховної Ради Української РСР. - 1981. - № 12. - Ст. Д79.

26. Управління стратегічним розвитком об’єднаних територіальних громад: інноваційні підходи та інструменти : монографія / С. М. Серьогін, Ю. П. Шаров,С. І. Бородін, Н. Т. Гончарук [та ін.] ; за заг. та наук. ред. С. М. Серьогіна, Ю. П. Шарова. - Д. : ДРІДУ НАДУ, 2016. - 276 с.].

27. Чернецький Ю. О. Стратегічне управління як інструмент забезпечення соціальної стабільності територіальної громади. Актуальні проблеми державного управління: Зб. наук. пр.: Другий Міжнар. наук. конгр. "Державне управління і місиеве самоврядування». - Вип. 2 (13). - Ч. 1 / Редкол.: Г. І. Мостовий, В. Я. Амбросов, В.С.Бакіров та ін.; Укр. Акад. держ. упр. при Президентові України, Харк. регіон. ін-т. - Х., 2002. C. 139-143. 